\title{
Effects of Intravenously Administered Fructose and Glucose on Splanchnic Amino Acid and Carbohydrate Metabolism in Hypertriglyceridemic Men
}

\author{
B. M. Wolfe, S. P. Ahuja, and E. B. Marliss \\ From the Westminster, Victoria, and University Hospitals and Department of \\ Medicine, University of Western Ontario, London, Ontario, and Department of \\ Medicine, University of Toronto, Toronto, Ontario, Canada
}

\begin{abstract}
A в S T R A C T Splanchnic metabolism was studied in the fed state during prolonged intravenous administration $(30 \mathrm{~g} / \mathrm{h})$ of either fructose or glucose to hypertriglyceridemic men who had been maintained on a highcarbohydrate diet for 2 wk. Splanchnic exchange of amino acids and carbohydrates was quantified by measurement of splanchnic flow and of blood or plasma arteriohepatic venous concentration gradients. Results obtained in subjects receiving fructose were compared with those obtained in (a) similar subjects receiving glucose and $(b)$ postabsorptive controls maintained on isocaloric, balanced diets.

Mean arterial plasma levels of alanine, glycine, serine, threonine, methionine, proline, valine, leucine, histidine, lysine, and ornithine were significantly higher in subjects given fructose than in those given glucose $(P<$ $0.05)$. The mean arterial concentration and splanchnic uptake of alanine were significantly higher in subjects given fructose than in postabsorptive controls, despite a significantly lower fractional extraction of alanine in the former $(P<0.05)$. The mean arterial plasma levels of serine and ornithine were significantly lower in subjects receiving fructose than in postabsorptive controls $(P<0.05)$.

About half of the administered fructose or glucose was taken up in the splanchnic region, where approximately $15 \%$ was converted to $\mathrm{CO}_{2}$ and $10 \%$ to lactate. Half of the fructose taken up in the splanchnic region was converted to glucose released from the liver. The amount of hexose carbon remaining for hepatic synthe-
\end{abstract}

Portions of this work were presented at the Annual Meeting of the Canadian Society for Clinical Investigation, 21 January 1975 (1). A preliminary report has appeared (2).

Received for publication 11 November 1974 and in revised form 17 June 1975. sis of lipids in subjects given fructose was less than half of that of subjects given glucose.

These studies demonstrate that fructose and glucose have divergent effects on amino acid metabolism and that during hypercaloric infusion of glucose (as with fructose), the human liver is a major site of lactate production.

\section{INTRODUCTION}

Fructose, widely distributed among plants as the free monosaccharide or as part of the disaccharide sucrose, accounts for one-sixth to one-third of total intake of dietary carbohydrates (3). It has also been given intravenously as a source of calories. Previous studies comparing the metabolism of fructose and glucose in postabsorptive man over short intervals have shown that fructose is utilized faster than glucose in diabetics (4) and that more is converted to liver glycogen (5). Although liver, gut (6), and kidney (7) have been shown to utilize fructose, there is a paucity of quantitative information about the role of extrasplanchnic tissues in the disposal of fructose. Glucose-stimulated insulin secretion has been reported to decrease splanchnic uptake of amino acids under some conditions (8) and insulin plus glucose to divert amino acids taken up by liver away from the gluconeogenic pathway (9). The effects of fructose administration on splanchnic metabolism of amino acids have not previously been reported.

We have studied patients in the fed state after prolonged, hypercaloric, constant, intravenous infusion of either fructose or glucose and have quantified and compared splanchnic exchange of amino acids and carbohydrates under steady-state conditions in two groups of asymptomatic hypertriglyceridemic men, one group given fructose and the other given equal amounts of glucose. 
TABLE I

Clinical Data

\begin{tabular}{cccccc}
\hline Group* & Subject & Age & Height & Weight & $\begin{array}{c}\text { Desirable } \\
\text { weight }\end{array}$ \\
\hline \multirow{4}{*}{ F } & M. S. & 29 & $c m$ & $k g$ & $\%$ \\
& J. P. & 36 & 167 & 71 & 112 \\
& R. Y. & 24 & 167 & 71 & 112 \\
& W. M. & 42 & 174 & 96 & 126 \\
& Mean \pm SE & $33 \pm 4$ & $173 \pm 4$ & $82 \pm 7$ & $121 \pm 5$ \\
G & D. B. & 33 & 170 & 123 & 184 \\
& H. F. & 50 & 160 & 76 & 127 \\
& G. R. & 28 & 174 & 104 & 146 \\
& G. C. & 30 & 196 & 100 & 116 \\
& Mean \pm SE & $35 \pm 5$ & $175 \pm 8$ & $101 \pm 10$ & $143 \pm 15$ \\
C & Mean \pm SE & $43 \pm 5$ & $172 \pm 3$ & $85 \pm 5$ & $126 \pm 11$ \\
\hline
\end{tabular}

* F, hypertriglyceridemic men given an intravenous infusion of fructose $(30 \mathrm{~g} / \mathrm{h}) ; \mathrm{G}$, hypertriglyceridemic men given an intravenous infusion of glucose $(30 \mathrm{~g} / \mathrm{h}) ; \mathrm{C}$, hypertriglyceridemic men fasted $15 \mathrm{~h}$, controls, from a previous study $(10,11)$

$\ddagger$ Based on tables by Hathaway and Foard (12).

The same conditions have permitted the study of splanchnic free fatty acid and triglyceride metabolism, the subject of a separate report. ${ }^{1}$

\section{METHODS}

The groups of subjects are described in Table $\mathrm{I}^{2}{ }^{2}$ Subjects who received fructose are designated group $F$ and those who received glucose group $\mathrm{G}$. The postabsorptive controls (group C) included four hypertriglyceridemic males previously described $(10,11)$. All subjects were asymptomatic and had no clinical evidence of disordered circulation. Each had hyperlipemia on entry into the lipid clinic (range of fasting serum triglycerides: $156-408 \mathrm{mg} / 100 \mathrm{ml}$; cholesterol: $167-305 \mathrm{mg} / 100 \mathrm{ml}$ ) ; however, one subject (R. Y.) became normolipemic (fasting serum triglycerides: $74 \mathrm{mg}$ / $100 \mathrm{ml}$ ) when he received the isocaloric diet. All subjects of groups $F$ and $G$ had normal levels of serum glucose while fasting and $2 \mathrm{~h}$ after a $100 \mathrm{-g}$ carbohydrate breakfast, except one subject (G. C.), who had evidence of mild glucose intolerance (2-h: postprandial serum glucose; $167 \mathrm{mg} /$ $100 \mathrm{ml}$ ). Each had normal serum concentrations of albumin, globulins, total and direct bilirubin, alkaline phosphatase, thyroxine, creatinine, calcium, sodium, potassium, chloride, and bicarbonate. Each had normal hematologic and urine analyses in addition to a normal chest roentgenogram. One subject (M. S.) had an elevated level of serum uric acid $(8.4 \mathrm{mg} / 100 \mathrm{ml})$.

Experimental procedures. The dietary preparation of group $\mathrm{C}$ has been described previously (10). All subjects of groups $F$ and $G$ maintained their body weight within $2 \mathrm{~kg}$ and consumed no ethanol during the 3-4 wk before the study of splanchnic metabolism. During the first 1-2 wk of this period, subjects were maintained on balanced diets calculated to maintain weight $\left(1,100 \mathrm{kcal} / \mathrm{m}^{2}\right.$ "desirable" body surface area (BSA)/day) and containing the

${ }^{1}$ Wolfe, B. M., and S. P. Ahuja. Mechanisms of carbohydrate accentuation of lipemia. Manuscript in preparation.

${ }^{2}$ The proposed study had bee:s fully explained to each man and informed, written consent was obtained.
TABLE II

Experimental Schedule

\begin{tabular}{cl}
\hline Time & \multicolumn{1}{c}{ Procedure } \\
\hline$h$ & \\
0 & Last evening meal (5 p.m.) \\
4 & Evening snack \\
14 & Start infusion of $10 \%$ fructose or glucose \\
18 & Begin administration of radioisotopes \\
20 & Catheterization of artery and hepatic vein \\
$21-23$ & Sampling of arterial and hepatic venous blood \\
$23-30$ & Sampling of blood from arm vein \\
\hline
\end{tabular}

following distribution of calories: $20 \%$ protein, $38 \%$ fat, and $42 \%$ carbohydrate (ratio of simple to complex carbohydrates, 1.0). Desirable BSA was calculated from the height and the corresponding suggested median weight for healthy young men (12). Thus, caloric intake during the isocaloric balanced diet ranged from 1,700 to $2,400 \mathrm{kcal} /$ day. Samples of venous blood were obtained (after a 12-15-h fast) for determination of plasma amino acids and other metabolites during this time. Subjects in groups $F$ and $G$ were placed on nonformula, hypercaloric high-carbohydrate diets $\left(1,400 \mathrm{kcal} / \mathrm{m}^{2}\right.$ desirable BSA/day: $12 \%$ protein, $13 \%$ fat, and $75 \%$ carbohydrate) 2 wk before the study of splanchnic metabolism and were admitted to the metabolic research ward of the hospital for strict dietary control for at least the last 10 days of this period. The high-carbohydrate diet was rich in sucrose (ratio of simple to complex carbohydrates, 2.5) and the ratio of polyunsaturated: monounsaturated: saturated fat was maintained at $1.0: 1.3$ : 1.0. Caloric intake during the high-carbohydrate diet ranged from 2,230 to $3,190 \mathrm{kcal} /$ day. Samples of venous blood were obtained (after a 12-15-h fast) on the 8th, 10th, and 12 th day of the high-carbohydrate diet. During the last 3 days before the study of splanchnic metabolism, the subjects of groups $F$ and $G$ were given an evening snack (containing approximately $100 \mathrm{~g}$ carbohydrate and less than $2 \mathrm{~g}$ fat) with adjustments in the other meals to maintain caloric composition and intake. The last evening meal preceding the study $(4 \mathrm{~h}$ before the last evening snack) contained less than $5 \mathrm{~g}$ fat with carbohydrate added to maintain constant caloric intake. See experimental schedule (Table II).

$10 \mathrm{~h}$ after the evening snack a constant intravenous infusion of either $10 \%$ fructose in water (group F) or $10 \%$ glucose in water (group G) was started via a silicone rubber catheter in an arm vein and maintained at the rate of $4.94 \mathrm{ml} / \mathrm{min}$ for $16 \mathrm{~h}$ by means of a motor-driven infusion pump. This represents a total dose of $480 \mathrm{~g}$ of either fructose or glucose, amounting to $1,920 \mathrm{kcal}$ in $16 \mathrm{~h}$. All urine was collected for measurement of fructose and glucose excretion throughout this period. $14 \mathrm{~h}$ after the evening snack, when steady levels of blood fructose and/or glucose could be expected, a pulse injection ${ }^{3}$ of tracer amounts $(<1 \mathrm{mg})$ of either sterile pyrogen-free $\left[\mathrm{U}-{ }^{14} \mathrm{C}\right]-$ fructose or $\left[\mathrm{U}^{14} \mathrm{C}\right]$ glucose equal to 120 times the amount

${ }^{3}$ The pulse injection of $\left[\mathrm{U}_{-14} \mathrm{C}\right]$ fructose was omitted in two subjects of group F (R. Y and W. M.); the specific activity of carbons of potassium gluconate derived from arterial blood glucose remained constant and similar to those of the administered fructose over the period 3-12 h after the onset of the isotopic infusion. 
of radioisotope infused per minute was given at the onset of a constant infusion of albumin-bound $\left[9,10-{ }^{3} \mathrm{H}\right]$ palmitate, indocyanine green $(0.8 \mathrm{mg} / \mathrm{min})$, and either $\left[\mathrm{U}^{14} \mathrm{C}\right]$ fructose $(0.14 \mu \mathrm{Ci} / \mathrm{min})$ or $\left[\mathrm{U}-{ }^{14} \mathrm{C}\right]$ glucose $(0.14 \mu \mathrm{Ci} / \mathrm{min})$ respectively. The total amounts of radioactivity infused (less than $120 \mu \mathrm{Ci}$ carbon-14 and $300 \mu \mathrm{Ci}$ tritium) were similar to those used in previous studies in man with these radioisotopes $(13,14)$. The infusions of indocyanine green and $\left[9,10-{ }^{3} \mathrm{H}\right]$ palmitate were given for 5 and $12 \mathrm{~h}$, respectively. Two subjects of group G (D. B. and H. F.) received a constant infusion of $\left[\mathrm{U}-{ }^{14} \mathrm{C}\right]$ glucose for only $5 \mathrm{~h}$; all others received infusions of either $\left[\mathrm{U}-{ }^{14} \mathrm{C}\right]$ fructose or [U- ${ }^{14} \mathrm{C}$ ] glucose for $12 \mathrm{~h}$.

$2 \mathrm{~h}$ after starting the isotopic infusion, a right hepatic vein and left brachial artery were catheterized and the blood volume was determined, as previously described (10, 11). In two obese subjects, D. B. and G. R., a dorsalis pedis artery was catheterized instead of a brachial artery. Simultaneous samples of arterial and hepatic venous blood were obtained at 20 -min intervals between 3 and $5 \mathrm{~h}$ and venous samples were obtained (from an arm vein) 5,8 , 10,11 , and $12 \mathrm{~h}$ after the onset of the isotopic infusion (10). Splanchnic plasma flow was measured as previously described $(10,15)$.

Analyses. These were as previously described $(10,11$, 15) for assay of glucose, lactate, glycerol, oxygen, and carbon dioxide. The method of Buhler (16) for counting $\left[{ }^{14} \mathrm{C} \mathrm{CO}_{2}\right.$ in blood was modified by substituting an equal volume of hyamine hydroxide for $\mathrm{KOH}$ as the trapping agent (17). Whole blood and plasma samples for measurement of free amino acids were deproteinized with an equal amount of $7.5 \%$ or $30 \%$ (wt/vol) of perchloric acid, respectively, and the supernatant fluid was stored at $-20^{\circ} \mathrm{C}$ for subsequent amino acid analyses. These were performed by automated ion-exchange chromatography on a Beckman $120 \mathrm{C}$ amino acid analyzer (Beckman Instruments Inc. Spinco Div., Palo Alto, Calif.) modified for single-column analysis of basic as well as acidic and neutral amino acids (18) with the equivalent of $125 \mu 1$ of sample before deproteinization. By the use of this protocol and lithium buffer systems, the glutathione present in the whole blood supernatant fluid is resolved as a single peak that does not interfere with the resolution of other amino acids.

Serum insulin was measured by a coated-charcoal radioimmunoassay (19) employing human insulin as standard, porcine monoiodinated $\left[{ }^{125} \mathrm{I}\right]$ insulin as tracer, and an antiserum. Duplicate $0.2-\mathrm{ml}$ samples of heparinized blood and urine (diluted 1:10 with water) were deproteinized with barium hydroxide and zinc sulphate (20) and fructose content was assayed by the method of Kulka (21). Blood fructose determinations were corrected for glucose reaction with the resorcinol by substracting $0.026 \mu \mathrm{mol}$ for each 1 $\mu \mathrm{mol}$ glucose determined with glucose oxidase. 5-ml samples of whole blood were deproteinized with perchloric acid and neutralized with potassium hydroxide for determination of specific activity of glucose and lactate (22). Isolation of the potassium gluconate derivative (23) showed more than $99 \%$ of the radioactivity was actually in glucose.

Coefficients of variation calculated from duplicate analyzes in these studies were $1.3 \%$ for glucose, $3.5 \%$ for ${ }^{14} \mathrm{C}$-labeled glucose, $2.7 \%$ for fructose, $2.9 \%$ for lactate, $3.9 \%$ for ${ }^{14} \mathrm{C}$-labeled lactate, $3.0 \%$ for glycerol, and $4.2 \%$ for $\left[{ }^{14} \mathrm{C}\right] \mathrm{CO}_{2}$.

Materials. Sterile, pyrogen-free $\left[\mathrm{U}-{ }^{14} \mathrm{C}\right]$ glucose $(3.9 \mathrm{mCi} /$ mmol) was obtained from New England Nuclear, Boston, Mass. Sterile, pyrogen-free $\left[\mathrm{U}-{ }^{14} \mathrm{C}\right]$ fructose $(275 \mathrm{mCi}$ / $\mathrm{mmol}$ ) was obtained from Mallinkrodt Chemical Works,
St. Louis, Mo. $\left[\mathrm{U}-{ }^{14} \mathrm{C}\right]$ Glucose and $\left[\mathrm{U}-{ }^{14} \mathrm{C}\right]$ fructose were certified over $98 \%$ pure. Indocyanine green was obtained as Cardio-Green (Hynson, Westcott \& Dunning, Inc., Baltimore, Md.). Porcine monoiodinated [ $\left.{ }^{125} \mathrm{I}\right]$ insulin was obtained from Novo Research Institute, Copenhagen, Denmark. Anti-insulin antiserum (lot 582) was provided by Dr. Peter Wright, Indianapolis, Ind. Hyamine hydroxide was obtained from G. D. Searle \& Co., Oakville, Ontario.

Calculations. The general equations used have been described $(10,11,15)$. Values for splanchnic uptake and/or release of metabolites and for conversion of $\left[\mathrm{U}^{14} \mathrm{C}\right]$ fructose or $\left[\mathrm{U}_{-}{ }^{14} \mathrm{C}\right]$ glucose to $\left[{ }^{14} \mathrm{C}\right] \mathrm{CO}_{2}$ and lactate were calculated from six or seven sets of simultaneous arterial and hepatic venous blood samples obtained at 20 -min intervals from 3 to $5 \mathrm{~h}$ after the isotopic infusion started. Values for splanchnic plasma and blood flow were based on four determinations from 3 to $5 \mathrm{~h}$ after the start of the isotopic infusion. Values for splanchnic $\mathrm{O}_{2}$ and $\mathrm{CO}_{2}$ exchange were based on two determinations between 3 and $4 \mathrm{~h}$ after the onset of the isotopic infusion. Values for arterial concentration of serum insulin were based on specimens obtained $4 \mathrm{~h}$ after the onset of the isotopic infusion.

Differences between groups were evaluated according to Snedecor and Cochran for both paired and unpaired samples (24). Variance was expressed as the standard error of the mean.

\section{RESULTS}

Groups of subjects. There were no significant differences among groups F, G, and $\mathrm{C}$ in age, height, weight, percent desirable weight (Table I), or serum triglyceride levels (data not shown).

Metabolism of amino acids. Except for threonine, which fell on the 12th day of the hypercaloric highcarbohydrate diet ( $125 \pm 9$ vs. $146 \pm 4 \mu \mathrm{M}, n=7)$, mean values for fasting levels of peripheral venous plasma amino acids on the 8th and 12th day of the high-carbohydrate diet were not significantly different from those obtained during ingestion of the isocaloric balanced diet. The respective mean values for seven subjects on the latter diet were alanine, $385 \pm 48 \mu \mathrm{M}$; glycine, $203 \pm 10$ $\mu \mathrm{M}$; serine, $116 \pm 9 \mu \mathrm{M}$; threonine, $146 \pm 4 \mu \mathrm{M}$; half cystine, $34 \pm 3 \mu \mathrm{M}$; phenylalanine, $64 \pm 4 \mu \mathrm{M}$; tyrosine, $67 \pm 6 \mu \mathrm{M}$; methionine, $42 \pm 3 \mu \mathrm{M}, n=4$; $\alpha$-aminobutyrate, $23 \pm 3 \mu \mathrm{M}$; valine, $259 \pm 21 \mu \mathrm{M}$; isoleucine, $101 \pm 10$ $\mu \mathrm{M}$; leucine, $163 \pm 12 \mu \mathrm{M}$; taurine $49 \pm 6 \mu \mathrm{M}$, citrulline, $31 \pm 4 \mu \mathrm{M}$; arginine, $126 \pm 15 \mu \mathrm{M}$; histidine, $106 \pm 9 \mu \mathrm{M}$; lysine, $234 \pm 15 \mu \mathrm{M}$; ornithine, $59 \pm 5 \mu \mathrm{M}$; and aspartic acid, $27 \pm 4 \mu \mathrm{M}$.

Arterial concentrations and splanchnic exchange of amino acids were strikingly different during infusion of fructose versus glucose. Mean arterial plasma concentrations of alanine, glycine, serine, threonine, methionine, proline, valine, leucine, histidine, lysine, and ornithine in group $\mathrm{F}$ were significantly higher than in group $\mathrm{G}$ $(P<0.05$, Table III $)$. The mean splanchnic extraction fraction and uptake of histidine and the splanchnic uptake of serine were significantly higher in group $F$ than in group $\mathrm{G}(P<0.05)$. Mean values for the 
splanchnic extraction fraction and uptake of proline and lysine and uptake of alanine in group $F$ were substantially higher than in group $\mathrm{G}$; however, the differences were not statistically significant $(P>0.05)$.

Mean values for splanchnic uptake of amino acids based on transsplanchnic gradients in whole blood times splanchnic blood flow were obtained for three subjects of group $F$ and were virtually identical to those based on transsplanchnic plasma gradients times splanchnic plasma flow for alanine ( $65 \pm 13$ vs. $64 \pm 9 \mu \mathrm{mol} /$ $\left.\mathrm{min} \cdot \mathrm{m}^{2}\right)$, serine $\left(15 \pm 4\right.$ vs. $\left.15 \pm 2 \mu \mathrm{mol} / \mathrm{min} \cdot \mathrm{m}^{2}\right)$, $\alpha$-aminobutyrate $(-2.9 \pm 0.1$ vs. $-2.5 \pm 1.6 \mu \mathrm{mol} / \mathrm{min}$. $\left.\mathrm{m}^{2}\right)$, lysine $\left(11 \pm 14\right.$ vs. $\left.12 \pm 6 \mu \mathrm{mol} / \mathrm{min} \cdot \mathrm{m}^{2}\right)$, and ornithine $\left(-0.9 \pm 3.6\right.$ vs. $\left.-0.8 \pm 2.6 \mu \mathrm{mol} / \mathrm{min} \cdot \mathrm{m}^{2}\right)$, respectively. Although the number of subjects was small, there were no significant differences in the splanchnic exchange of any other amino acids between values based on plasma gradients times splanchnic plasma flow and those based on gradients in whole blood times splanchnic blood flow.

Mean arterial concentration and splanchnic uptake of alanine in group $F$ were significantly higher than in three healthy male controls who had fasted $15 \mathrm{~h}^{4}$ (665士 79 vs. $159 \pm 21 \mu \mathrm{M}$ and $60.4 \pm 6.1$ vs. $33.2 \pm 2.1 \mu \mathrm{mol} / \mathrm{min}$. $\mathrm{m}^{2}$, respectively, $P<0.05$ ), despite a significantly lower mean splanchnic extraction fraction of alanine in the former $(0.25 \pm 0.07$ vs. $0.59 \pm 0.03, P<0.05)$. However, the mean arterial plasma concentration of serine of group $F$ was significantly lower than that of the three healthy male controls fasted $15 \mathrm{~h}(97 \pm 9$ vs. $136 \pm 3 \mu \mathrm{M}$, $P<0.05)$. The mean arterial plasma concentration of ornithine of group $F$ was significantly lower $(41 \pm 3$ vs. $89 \pm 5 \mu \mathrm{M}, P<0.05)$, and that of arginine significantly higher $(82 \pm 2$ vs. $48 \pm 4 \mu \mathrm{M}, P<0.05)$ than previously reported for healthy men fasted 10-14 h (25).

The mean arterial plasma concentrations of serine $(50 \pm 3$ vs. $136 \pm 3 \mu \mathrm{M})$, phenylalanine ( $28 \pm 4$ vs. $42 \pm 2$ $\mu \mathrm{M})$, tyrosine $(26 \pm 3$ vs. $37 \pm 0 \mu \mathrm{M})$, methionine $(6 \pm 2$ vs. $19 \pm 0 \mu \mathrm{M}), \alpha$-aminobutyrate $(7 \pm 1$ vs. $27 \pm 4 \mu \mathrm{M})$, valine $(111 \pm 9$ vs. $213 \pm 4 \mu \mathrm{M})$, isoleucine (25 \pm 4 vs. $59 \pm 5 \mu \mathrm{M}$ ), and leucine ( $54 \pm 7$ vs. $117 \pm 7 \mu \mathrm{M}$ ) of group $\mathrm{G}$ were significantly lower than those of the three healthy male controls who had fasted $15 \mathrm{~h}(P<0.05)$. The mean arterial plasma concentrations of histidine $(47 \pm 5$ vs. $84 \pm 3 \mu \mathrm{M})$, lysine $(114 \pm 9$ vs. $165 \pm 9 \mu \mathrm{M})$, and ornithine $(23 \pm 3$ vs. $87 \pm 5 \mu \mathrm{M})$, of group $\mathrm{G}$ were significantly lower $(P<0.05)$ than previously reported for healthy men fasted $10-14 \mathrm{~h}$ (25). The mean arterial plasma concentration of aspartic acid of group $G$ was also significantly lower $(5 \pm 1$ vs. $10 \pm 1, P<0.05)$ than previously reported for healthy men fasted $12-14 \mathrm{~h}(26)$.

"Wolfe, B. M., R. J. Havel, E. B. Marliss, J. P. Kane, and J. Seymour. Unpublished data.
TABLE III

Arterial Concentrations and Splanchnic Extraction and Exchange of Plasma Amino Acids*

\begin{tabular}{|c|c|c|c|c|}
\hline & Group & $\begin{array}{c}\text { Arterial } \\
\text { concen- } \\
\text { tration }\end{array}$ & $\begin{array}{c}\text { Extraction } \\
\text { fraction }\end{array}$ & $\begin{array}{c}\text { Splanchnic } \\
\text { uptake }\end{array}$ \\
\hline & & $\mu m o l / m l$ & & $\mu \mathrm{mol} / \mathrm{min} \cdot \mathrm{m}$ \\
\hline \multirow[t]{2}{*}{ Alanine } & $F$ & $665 \pm 79$ & $0.25 \pm 0.07$ & $60.4 \pm 6.1$ \\
\hline & G & $201 \pm 27 \ddagger$ & $0.34 \pm 0.09$ & $26.0 \pm 9.7$ \\
\hline \multirow[t]{2}{*}{ Glycine } & $\mathrm{F}$ & $212 \pm 13$ & $0.11 \pm 0.07$ & $7.3 \pm 4.3$ \\
\hline & G & $140 \pm 17_{\ddagger}^{+}$ & $-0.11 \pm 0.10$ & $-5.8 \pm 4.6$ \\
\hline \multirow[t]{2}{*}{ Serine } & $\mathrm{F}$ & $97 \pm 9$ & $0.35 \pm 0.08$ & $13.0 \pm 2.0$ \\
\hline & G & $50 \pm 3 \ddagger$ & $0.26 \pm 0.08$ & $4.4 \pm 1.1+$ \\
\hline \multirow[t]{2}{*}{ Threonine } & $\mathrm{F}$ & $107 \pm 7$ & $0.12 \pm 0.09$ & $4.4 \pm 2.7$ \\
\hline & G & $50 \pm 6+$ & $-0.02 \pm 0.20$ & $0.5 \pm 3.8$ \\
\hline \multirow[t]{2}{*}{ Phenylalanine } & $\mathrm{F}$ & $44 \pm 5$ & $0.12 \pm 0.07$ & $2.6 \pm 2.0$ \\
\hline & G & $28 \pm 4$ & $-0.08 \pm 0.05$ & $-0.6 \pm 0.8$ \\
\hline \multirow[t]{2}{*}{ Tyrosine } & $\mathrm{F}$ & $49 \pm 8$ & $0.18 \pm 0.11$ & $3.1 \pm 1.6$ \\
\hline & G & $26 \pm 3$ & $0.27 \pm 0.10$ & $2.5 \pm 1.1$ \\
\hline \multirow[t]{2}{*}{ Methionine } & $\mathrm{F}$ & $18 \pm 2$ & $0.04 \pm 0.27$ & $0.3 \pm 2.2$ \\
\hline & G & $6 \pm 2+$ & $0.41 \pm 0.13$ & $1.1 \pm 0.1$ \\
\hline \multirow[t]{2}{*}{ Proline } & $\mathrm{F}$ & $257 \pm 23$ & $0.25 \pm 0.11$ & $24.6 \pm 9.8$ \\
\hline & G & $112 \pm 22_{+}^{+}$ & $-0.07 \pm 0.12$ & $-0.3 \pm 5.7$ \\
\hline \multirow[t]{2}{*}{$\alpha$-Aminobutyrate } & $\mathrm{F}$ & $19 \pm 4$ & $-0.08 \pm 0.22$ & $-0.7 \pm 1.7$ \\
\hline & G & $7 \pm 1$ & $0.24 \pm 0.08$ & $0.7 \pm 0.2$ \\
\hline \multirow[t]{2}{*}{ Valine } & $\mathrm{F}$ & $2.39 \pm 30$ & $-0.07 \pm 0.14$ & $-7.4 \pm 11.0$ \\
\hline & G & $111 \pm 9 \ddagger$ & $-0.11 \pm 0.14$ & $-3.7 \pm 5.2$ \\
\hline \multirow[t]{2}{*}{ Isoleucine } & $\mathrm{F}$ & $57 \pm 11$ & $0.02 \pm 0.11$ & $0.1 \pm 3.3$ \\
\hline & G & $25 \pm 4$ & $-0.19 \pm 0.18$ & $-1.5 \pm 1.5$ \\
\hline \multirow[t]{2}{*}{ Leucine } & $\mathrm{F}$ & $119 \pm 10$ & $0.15 \pm 0.09$ & $8.4 \pm 5.6$ \\
\hline & G & $54 \pm 7_{+}^{+}$ & $-0.08 \pm 0.10$ & $-1.2 \pm 1.6$ \\
\hline \multirow[t]{2}{*}{ Taurine } & $\mathrm{F}$ & $54 \pm 9$ & $-0.16 \pm 0.04$ & $-3.6 \pm 0.9$ \\
\hline & G & $37 \pm 4$ & $0.02 \pm 0.15$ & $0.1 \pm 1.8$ \\
\hline \multirow[t]{2}{*}{ Citrulline } & $\mathrm{F}$ & $17 \pm 3$ & $-0.33 \pm 0.32$ & $-0.7 \pm 2.5$ \\
\hline & G & $14 \pm 4$ & $-0.55 \pm 0.12$ & $-1.0 \pm 1.2$ \\
\hline \multirow[t]{2}{*}{ Arginine } & $\mathrm{F} \S$ & $82 \pm 2$ & $0.03 \pm 0.06$ & $1.4 \pm 1.9$ \\
\hline & G\& & $53 \pm 3$ & $0.18 \pm 0.2 .3$ & $3.1 \pm 4.3$ \\
\hline \multirow[t]{2}{*}{ Histidine } & $\mathrm{F}$ & $90 \pm 12$ & $0.32 \pm 0.04$ & $11.0 \pm 2.9$ \\
\hline & G & $47 \pm 5 \ddagger$ & $-0.04 \pm 0.08 \ddagger$ & $-2.2 \pm 0.2_{\ddagger}^{\ddagger}$ \\
\hline \multirow[t]{2}{*}{ Lysine } & $\mathrm{F}$ & $2.38 \pm 32$ & $0.22 \pm 0.10$ & $24.7 \pm 1.3 .8$ \\
\hline & G & $114 \pm 9_{+}^{+}$ & $-0.09 \pm 0.03$ & $-3.7 \pm 1.1$ \\
\hline \multirow[t]{2}{*}{ Ornithine } & $\mathrm{F}$ & $41 \pm 3$ & $0.07 \pm 0.16$ & $1.6 \pm 3.0$ \\
\hline & G & $23 \pm 3 \ddagger$ & $0.01 \pm 0.12$ & $0.2 \pm 1.0$ \\
\hline \multirow[t]{2}{*}{ Aspartic acid } & $\mathrm{F}$ & $15 \pm 5$ & $0.03 \pm 0.16$ & $0.7 \pm 1.1$ \\
\hline & G & $5 \pm 1$ & $-1.58 \pm 0.64$ & $-2.4 \pm 0.4$ \\
\hline
\end{tabular}

* Mean values $\pm \mathrm{SE}$ for four subjects given an intravenous infusion of fructose $(30 \mathrm{~g} / \mathrm{h}$ ) for $9 \mathrm{~h}$ (group $\mathrm{F}$ ) and four subjects given an intravenous infusion of glucose $(30 \mathrm{~g} / \mathrm{h})$ for $9 \mathrm{~h}$ (group $\mathrm{G})$

$\ddagger$ Significantly different from $F, P<0.05$.

$\$$ Values for two subjects only.

TABLE IV

Hemodynamic and Other Data Obtained during Study of Splanchnic Metabolism*

\begin{tabular}{ccccc}
\hline & & \multicolumn{3}{c}{ Splanchnic } \\
\cline { 3 - 5 } Group & Plasma volume & $\begin{array}{c}\text { Plasma } \\
\text { flow }\end{array}$ & $\begin{array}{c}\text { Blood } \\
\text { flow }\end{array}$ & $\begin{array}{c}\mathrm{O}_{2} \\
\text { consumption }\end{array}$ \\
\hline & liter $/ \mathrm{m}^{2}$ & $\mathrm{ml} / \mathrm{min} \cdot \mathrm{m}^{2}$ & $\mathrm{ml} / \mathrm{min} \cdot \mathrm{m}^{2}$ & $\mathrm{mmol} / \mathrm{min} \cdot \mathrm{m}^{2}$ \\
F & $1.76 \pm 0.08+$ & $\mathbf{4 2 0} \pm 70$ & $740 \pm 120$ & $1.28 \pm 0.08 \S$ \\
$\mathrm{G}$ & $1.66 \pm 0.11$ & $362 \pm 9$ & $652 \pm 15$ & $1.64 \pm 0.02$ \\
$\mathrm{C}$ & $1.36 \pm 0.08$ & $\mathbf{4 0 2} \pm \mathbf{4 4}$ & $725 \pm 81$ & $1.81 \pm 0.18$ \\
\hline
\end{tabular}

* Mean value $\pm \mathrm{SE}$ for four subjects in each group.

$¥$ Significantly different from $C, P<0.05$.

$\S$ Significantly different from G, $P<0.05$. 
TABLE V

Arterial Concentrations and Splanchnic Uptake and Utilization of Hexoses*

\begin{tabular}{|c|c|c|c|c|c|c|c|c|c|}
\hline \multirow[b]{2}{*}{ Group } & \multicolumn{2}{|c|}{ Arterial blood concentration } & \multicolumn{2}{|c|}{ Splanchnic uptake } & \multicolumn{5}{|c|}{ Rates of splanchnic conversion to } \\
\hline & Fructose & Glucose & Fructose & Glucose & Glucoset & $\mathrm{CO}_{2} \ddagger$ & Lactateł & Sum $\ddagger$ & Remainder $\neq$ \\
\hline & \multicolumn{2}{|c|}{$\mu \mathrm{mol} / \mathrm{ml}$} & \multicolumn{2}{|c|}{$\mu \mathrm{mol} / \mathrm{min} \cdot \mathrm{m}^{2}$} & \multicolumn{5}{|c|}{$\mu \mathrm{mol} / \mathrm{min} \cdot \mathrm{m}^{2}$} \\
\hline $\mathrm{F}$ & $2.0 \pm 0.1$ & $5.1 \pm 0.1$ & $658 \pm 82$ & - & $342 \pm 79$ & $91 \pm 12$ & $47 \pm 14$ & $480 \pm 67$ & $178 \pm 90$ \\
\hline G & - & $9.3 \pm 0.1 \S$ & - & $501 \pm 21$ & - & $77 \pm 10$ & $55 \pm 4$ & $132 \pm 8 \S$ & $369 \pm 26$ \\
\hline
\end{tabular}

* Mean values $\pm \mathrm{SE}$ for four subjects given an intravenous infusion $(30 \mathrm{~g} / \mathrm{h})$ of either fructose (group F) or glucose (group G). For each subject, the value is the mean of six to seven measurements obtained $7-9 \mathrm{~h}$ after starting the infusion.

$\ddagger$ Micromoles of administered hexose converted to respective product(s).

$\S$ Significantly different from $\mathrm{F}, P<0.025$.

Consistently positive values, indicating a net splanchnic uptake, were demonstrable for three amino acids in group $F$ (alanine, serine, and proline) and for four in group G (alanine, serine, tyrosine, and $\alpha$-aminobutyrate). Consistently negative values, indicating a net splanchnic release, were demonstrable for histidine and lysine in group $\mathrm{G}$ and for taurine in group $\mathrm{F}$.

Hemodynamic data. Mean plasma volume in group $\mathrm{F}$ was significantly higher than in group $C(P<0.05)$, but was similar in groups $F$ and $G$ (Table IV). Mean splanchnic plasma flow was similar in groups $F, G$, and $\mathrm{C}$, as was blood flow. Mean splanchnic $\mathrm{O}_{2}$ consumption was lower in group $F$ than in either groups $G$ or $C$; however, only the difference between group $\mathrm{F}$ and $\mathrm{C}$ was statistically significant $(P<0.05)$. Mean hepatic venous $\mathrm{O}_{2}$ concentration was similar in groups $\mathrm{F}, \mathrm{G}$, and $\mathrm{C}(6.0 \pm 0.3,5.6 \pm 0.2$, and $5.6 \pm 02 \mathrm{mM}$, respectively).

Metabolism of fructose and glucose. Mean values for serial arterial and peripheral venous blood concentrations of fructose and glucose were essentially constant over the period 3-12 $\mathrm{h}$ after the start of the isotopic in-

TABLE VI

Disposal of Intravenously Administered Hexoses*

\begin{tabular}{|c|c|c|c|}
\hline \multirow[b]{2}{*}{ Group } & \multicolumn{2}{|c|}{ Percent removed by: } & \multirow[b]{2}{*}{$\begin{array}{l}\text { Percent excreted } \\
\text { in urine }\end{array}$} \\
\hline & $\begin{array}{l}\text { Extrasplanchnic } \\
\text { region } \ddagger\end{array}$ & $\begin{array}{l}\text { Splanchnic } \\
\text { region }\end{array}$ & \\
\hline & \multicolumn{2}{|c|}{$\%$} & $\%$ \\
\hline $\mathrm{F}$ & $52 \pm 5$ & $46 \pm 5$ & $2 \pm 0.4$ \\
\hline G & $61 \pm 1$ & $39 \pm 1 \S$ & 0 \\
\hline
\end{tabular}

* Mean values $\pm \mathrm{SE}$ for four subjects given an intravenous infusion $(30 \mathrm{~g} / \mathrm{h})$ of either fructose (group F) or glucose (group G). For each subject, the value is the mean of six to seven determinations obtained 7-9 $\mathrm{h}$ after starting the infusion of hexose.

$\ddagger 100 \%$ - (\% removed by splanchnic region $+\%$ excreted in urine).

$\S$ Significantly different from fraction removed by extrasplanchnic region, $P<0.005$. fusions. The mean arterial blood level of glucose in group $\mathrm{F}$ was significantly lower $(P<0.025)$ than in group $\mathrm{G}$ (Table V) ; however, there were no significant differences between groups $\mathrm{F}$ and $\mathrm{C}$ in the mean arterial blood concentration $(5.1 \pm 0.1$ vs. $6.4 \pm 0.4 \mathrm{mM})$ or mean splanchnic production of glucose $(342 \pm 79$ vs. $520 \pm 170$ $\left.\mu \mathrm{mol} / \mathrm{min} \cdot \mathrm{m}^{2}\right)$, respectively $(P>0.1$, see ref. 10$)$. The mean arterial blood level of fructose in group $F(2.0 \pm$ $0.1 \mathrm{mM}$ ) was in the expected range. The mean arterial serum concentration of insulin after an 8-h infusion of hexose was significantly lower in group $\mathrm{F}$ than in group G $(17 \pm 3$ vs. $94 \pm 20 \mu \mathrm{U} / \mathrm{ml}, P<0.05)$.

The fate of intravenously administered hexoses is shown in Table VI. Urinary excretion of glucose was negligible, as expected, since the arterial blood glucose level never exceeded $180 \mathrm{mg} / 100 \mathrm{ml}$. Values for absolute rates of uptake of administered hexose in the extrasplanchnic region were similar in groups $\mathrm{F}$ and $\mathrm{G}$ (765 \pm 65 vs. $793 \pm 63 \mu \mathrm{mol} / \mathrm{min} \cdot \mathrm{m}^{2}$, respectively). Mean splanchnic fractional extraction of fructose in group $F$ $(0.46 \pm 0.02)$ was significantly higher than that of glucose in group $\mathrm{G}(0.086 \pm 0.002, P<0.001)$; however, the higher arterial blood level of glucose compensated for the lower fractional extraction. Values for fractional extraction of hexoses did not vary systematically over the 3-5 h after the onset of the isotopic infusion.

The fate of hexoses removed in the splanchnic region expressed in absolute values is shown in Table $\mathrm{V}$ and

TABLE VII

Splanchnic Conversion of Hexoses to Metabolic Products*

Percent of hexose removed by splanchnic region converted to:

\begin{tabular}{cccccc}
\cline { 2 - 5 } Group & Glucose & $\mathrm{CO}_{2}$ & Lactate & Sum & Remainder \\
\hline F & $53 \pm 12$ & $14 \pm 0.3$ & $8 \pm 3$ & $75 \pm 11_{\ddagger}^{\ddagger}$ & $25 \pm 11 \ddagger$ \\
G & - & $16 \pm 2$ & $11 \pm 0.4$ & $27 \pm 2$ & $73 \pm 2$ \\
\hline
\end{tabular}

* Mean value $\pm \mathrm{SE}$ for four subjects given an intravenous infusion $(30 \mathrm{~g} / \mathrm{h})$ of either fructose (group F) or glucose (group G). For each subject, the value is the mean of six to seven measurements obtained $7-9 \mathrm{~h}$ after starting the infusion of hexose.

$\ddagger$ Significantly different from G, $P<\mathbf{0 . 0 2 5}$. 
in percent distribution in Table VII. Oxidation of glucose to $\left[{ }^{14} \mathrm{C}\right] \mathrm{CO}_{2}$ accounted for $36 \pm 5 \%$ of total splanchnic $\mathrm{CO}_{2}$ production $\left(1.32 \pm 0.09 \mathrm{mmol} / \mathrm{min} \cdot \mathrm{m}^{2}\right)$ in group G. There was a highly significant production of lactate by the splanchnic region in group $\mathrm{G}(P<0.001)$; splanchnic production of lactate in group $F$ was likewise significant $(P<0.05)$. The mean specific activity of carbons of arterial blood lactate $3 \mathrm{~h}$ after the onset of the isotopic infusion was $95 \pm 13 \%$ of that of the $\left[\mathrm{U}-{ }^{14} \mathrm{C}\right]-$ fructose administered in group $F$. Glucose released from the liver during administration of fructose appears to be derived essentially from the latter, because the mean specific activity of the carbons of arterial blood glucose (determined by isolation of glucose as the potassium gluconate derivative) was not significantly different from that of the $\left[\mathrm{C}^{14} \mathrm{C}\right]$ fructose administered in group F ( $12 \pm 1$ vs. $10 \pm 1 \mathrm{cpm} / \mu$ atom carbon, respectively, $P>$ 0.1 ). Similarly, in group $G$, there was no evidence of synthesis of glucose from unlabeled precursors because the specific activity of arterial blood glucose was $98 \pm 8 \%$ of that of the $\left[\mathrm{U}_{-}{ }^{14} \mathrm{C}\right]$ glucose administered.

Mean values for serial arterial and peripheral blood concentrations of lactate and glycerol were essentially constant over the period $3-12 \mathrm{~h}$ after the start of the isotopic infusion. The mean arterial blood level of lactate in group $\mathrm{F}$ was significantly higher than that of groups $G$ or $C(2.1 \pm 0.2$ vs. $1.0 \pm 0.0$ and $0.29 \pm 0.03 \mathrm{mM}$, respectively, $P<0.05$ ). The difference between the lactate concentration in groups $\mathrm{G}$ and $\mathrm{C}$ was also significant $(P<0.001)$. Values for mean arterial blood concentration $(45 \pm 9$ vs. $37 \pm 4 \mu \mathrm{M})$, splanchnic extraction fraction $(0.64 \pm 0.05$ vs. $0.79 \pm 0.03)$, and splanchnic uptake $\left(23 \pm 7\right.$ vs. $\left.19 \pm 3 \mu \mathrm{mol} / \mathrm{min} \cdot \mathrm{m}^{2}\right)$ of glycerol were not significantly different between groups $F$ and $G$, respectively $(P>0.05)$. Values for the mean arterial blood concentration $(62 \pm 8 \mu \mathrm{M})$ and splanchnic uptake $\left(30 \pm 3 \mu \mathrm{mol} / \mathrm{min} \cdot \mathrm{m}^{2}\right)$ of glycerol in group $\mathrm{C}(n=3)$ were somewhat higher than those in groups $\mathrm{F}$ and $\mathrm{G}$, but the differences were not significant $(P>0.05)$.

\section{DISCUSSION}

The fed state induced by administration of hypercaloric amounts of fructose or glucose is characterized by their rapid oxidation $(27,28)$ or conversion to glycogen and fat, contrasting with the catabolism of glycogen, fat, and protein in the postabsorptive state. The present studies were performed in a nutritional setting that would be expected to promote a high rate of carbohydrate utilization (29). The failure of fructose to stimulate insulin release (30) and the likelihood of differences in the relationship of insulin to glucagon during administration of the different hexoses may underlie many of the observed differences in the handling of metabolites (31).
Metabolism of amino acids. Neither hypertriglyceridemia per se nor a high-carbohydrate diet appears to influence fasting peripheral plasma amino acid concentrations, with the exception of threonine, which fell during the high-carbohydrate diet. Concentrations of plasma amino acids of postabsorptive hypertriglyceridemic subjects were in the range previously reported for healthy subjects $(32,33)$. Previous studies in the postabsorptive state have shown a decrease in the concentration of plasma amino acids after an oral glucose load (34-36) or during a brief intravenous infusion of glucose (8, 37); however, concentrations were generally much lower during the prolonged glucose infusions used in the present study. The low levels and the somewhat decreased splanchnic uptake of amino acids during glucose administration (Table III) are consistent with diminished release from the peripheray (31) and/or increased uptake by extrasplanchnic tissues, such as muscle, resulting from endogenous glucose-stimulated insulin secretion (38). The finding that splanchnic uptake of amino acids during hypercaloric infusion of glucose was not substantially different from that of postabsorptive healthy subjects $(25,26)$ is in accord with a study in which smaller amounts of glucose were given briefly (39). Oral glucose (40) or higher rates of intravenous glucose infusion of brief duration appreciably diminish splanchnic uptake of amino acids (8).

The high splanchnic uptake of alanine during fructose administration suggests increased alanine release from the extrasplanchnic region. The precursor $(s)$ of the excess alanine, present in high concentration, is uncertain; however, it is tempting to speculate it may have been formed in muscle via transamination of pyruvate formed through glycolysis of glucose that was derived from fructose. Fructose is taken up in muscle $(3,5,41-$ 43 ) as well as adipose tissue (44), lung, salivary glands (45), and kidney $(7,46)$. Direct evidence of rapid interconversion of glucose and fructose in muscle through transhydrogenation via glucitol has been recently reported (47). As such, fructose could function in parallel to glucose in the activity of the "glucose-alanine" cycle (48). The similarity of the specific activities of the carbons of blood glucose and lactate and of the $\left[\mathrm{U}^{-14} \mathrm{C}\right]-$ fructose administered is in accord with this hypothesis. Since plasma alanine levels are elevated by fructose, it might be useful in hypoglycemic states attributable to inadequate substrate supply for gluconeogenesis $(49,50)$.

Splanchnic metabolism of fructose and glucose. About one-half of the fructose administered was taken up in the splanchnic region (Table VI) where the fraction extracted averaged $46 \%$ (see Results). Approximately $10 \%$ of the fructose taken up in the splanchnic region may be extracted by extrahepatic splanchnic tissues (41). Conversion to glucose that was released into the 
hepatic vein accounted for about one-half of the fructose taken up in the splanchnic region (Table VII), a value an order of magnitude higher than that previously observed (46). Measurements of extrahepatic splanchnic glucose uptake in glucose-fed miniature swine ${ }^{5}$ suggest that extrahepatic splanchnic uptake may account for about $20 \%$ of splanchnic glucose uptake during hypercaloric intravenous glucose infusion in man.

Liver is an unrecognized major source of lactate in the glucose-fed state in man, swine (51), and dogs (52), and may be a source of lactate taken up in muscle after an oral glucose load (53). Splanchnic production of lactate in group F was 5-10-fold lower than previously reported $(41,46)$; however, the former could account for a similar fraction of splanchnic fructose uptake. The similar concentrations of lactate in superior mesenteric venous and arterial blood during fructose administration in man (41) and in portal venous and arterial blood during glucose administration in miniature swine ${ }^{5}$ suggest that the lactate released into the hepatic vein is formed essentially in liver. Lactate production by erythrocytes in transit through the splanchnic circulation accounts for less than $10 \%$ of splanchnic lactate production, calculated with the accepted values for mean transit time (54) and erythrocytic lactate production (55).

Release into the hepatic vein of glucose, $\left[{ }^{14} \mathrm{C}\right] \mathrm{CO}_{2}$, and lactate plus a small allowance for pyruvate (56) could account for about $80 \%$ of fructose removed in the splanchnic region during the intravenous administration of fructose (Table VII). Release of $\left[{ }^{14} \mathrm{C}\right] \mathrm{CO}_{2}$, lactate, and pyruvate (57) could account for only about $30 \%$ of glucose removed in the splanchnic region in subjects given glucose. The remaining hexose would be available for conversion to glycogen (5) and/or triglycerides (58). Blood pyruvate levels are reported to rise during administration of either hexose $(41,56,57)$.

\section{ACKNOWLEDGMENTS}

We are grateful to Dr. C. Tao and C. Sammut for expert technical assistance and to E. Wolfe for helping with all aspects of this investigation.

This work was supported by a grant from the Medical Research Council of Canada (MA 4248).

${ }^{5}$ Wolfe, B. M., and L. W. Belbeck. Unpublished observations.

\section{REFERENCES}

1. Wolfe, B. M., S. P. Ahuja, and E. B. Marliss. 1974. Fructose-induced hyperalaninemia : differential effects of fructose and glucose on splanchnic metabolism in man. Clin. Res. 22: 753A. (Abstr.)

2. Wolfe, B. M., and S. P. Ahuja. 1972. Splanchnic production of $\mathrm{L}(t)$ lactate in man during hypercaloric glucose infusion. Clin. Res. 20: 757A. (Abstr.)

B. M. Wolfe, S. P. Ahuja, and E. B. Marliss
3. Froesch, E. R. 1972. Essential fructosuria and heritary fructose intolerance. Metab. Basis Inherited Dis. 3: $131-148$.

4. Smith, L. H., R. H. Ettinger, and D. Seligson. 1953. A comparison of the metabolism of fructose and glucose in hepatic disease and diabetes mellitus. J. Clin. Invest. 32: 273-282.

5. $\mathrm{H}$ :son Nilsson, L., and E. Hultman. 1974. Liver and muscle glycogen in man after glucose and fructose infusion. Scand. J. Clin. Lab. Invest. 33: 5-10.

6. Bollman, J. L., and F. C. Mann. 1931 The physiology of the liver. XIX. The utilization of fructose following complete removal of the liver. Am. J. Physiol. 96: 683695.

7. Reinecke, R. M. 1944. The kidney as a locus of fructose metabolism. Am. J. Physiol. 141: 669-676.

8. Felig, P., and J. Wahren. 1971. Influence of endogenous insulin secretion on splanchnic glucose and amino acid metabolism in man. J. Clin. Invest. 50: 1702-1711.

9. Liljenquist, J. E., J.-L. Chiasson, F. E. Finger, and W. W. Lacy. 1974. Differential effect of insulin on glycogenolysis and gluconeogenesis. Diabetes. 23 (Suppl. 1) : 349 .

10. Havel, R. J., J. P. Kane, E. O. Balasse, N. Segal, and L. V. Basso. 1970. Splanchnic metabolism of free fatty acids and production of triglycerides of very low density lipoproteins in normotriglyceridemic and hypertriglyceridemic humans J. Clin. Invest. 49: 2017-2035.

11. Wolfe, B. M., J. P. Kane, R. J. Havel, and H. P. Brewster. 1973. Mechanism of the hypolipemic effect of clofibrate in postabsorptive man. J. Clin. Invest. 52: 2146-2159.

12. Hathaway, M. L., and E. D. Foard. 1960. Heights and weights of adults in the United States. Home Economics Research Report No. 10, U. S. Government Printing Office, Washington, D. C.

13. Fine, M., G. Michaels, S. Shah, B. Chai, G. Fukayama, and L. Kinsell. 1962. The incorporation of $\mathrm{C}^{14}$ from uniformly labeled glucose into plasma triglycerides in normals and hyperglyceridemics. Metab. Clin. Exp. 11: 893-911.

14. Farquhar, J. W., R. C. Gross, R. M. Wagner, and G. M. Reaven. 1965. Validation of an incompletely coupled two-compartment nonrecycling catenary model for turnover of liver and plasma triglyceride in man J. Lipid Res. 6: 119-134.

15. Wolfe, B. M., and L. W. Belbeck. 1975. Splanchnic and hepatic triglyceride secretion during hypercaloric intravenous glucose infusion in conscious swine. J. Lipid. Res. 16: 19-27.

16. Buhler, D. R. 1962. A simple scintillation counting technique for assaying $\mathrm{C}^{14} \mathrm{O}_{2}$ in a Warburg flask. Anal. Biochem. 4 : 413-417.

17. White, L. W. 1971. Regulation of hepatic cholesterol biosynthesis by clofibrate administration. J. Pharmacol. Exp. Ther. 178: 361-370.

18. Kedenburg, C.-P. 1971. A lithium buffer system for accelerated single-column amino acid analysis in physiological fluids. Anal. Biochem. 40: 35-42.

19. Herbert, V., K.-S. Lau, C. W. Gottlieb, and S. J. Bleicher. 1965. Coated charcoal immunoassay of insulin. J. Clin. Endocrinol. Metab. 25: 1375-1384.

20. Somogyi, M. 1945. Determination of blood sugar. $J$. Biol. Chem. 160: 69-73.

21. Kulka, R. G. 1956. Colorimetric estimation of keptopentoses and ketohexoses. J. Biochem (Tokyo). 63: $542-548$. 
22. Kreisberg, R. A., W. C. Owen, and A. M. Siegal. 1971. Ethanol-induced hyperlacticacidemia: inhibition of lactate utilization. J. Clin. Invest. 50: 166-174.

23. Blair, A., and S. Segal. 1960. The isolation of blood glucose as potassium gluconate. J. Lab. Clin. Med. 55: 959-964.

24. Snedecor, G. W., and W. G. Cochran. 1967. Statistical Methods. Iowa State University Press, Ames, Iowa. 6th edition. 114.

25. Felig, P., and J. Wahren. 1971. Amino acid metabolism in exercising man. J. Clin. Invest. 50: 2703-2714.

26. Wahren, J., P. Felig, E. Cerasi, and R. Luft. 1972. Splanchnic and peripheral glucose and amino acid metabolism in diabetes mellitus. J. Clin. Invest. 51: 1870-1878.

27. Carpenter, T. M., and R. C. Lee. 1933. The effect of glucose and of fructose on the human respiratory quotient and alveolar air. J. Nutr. 6: 55-82.

28. Shipley, R. A., E. B. Chudzik, and A. P. Gibbons. 1970. Rate of disposal of glucose carbon to $\mathrm{CO}_{2}$, fat, protein, and glycogen in the diabetic rat. Am. J. Physiol. 219: 364-373.

29. Salas, M., E. Viñuela, and A. Sols. 1963. Insulin-dependent synthesis of liver glucokinase in the rat. J. Biol. Chem. 238: 3535-3538.

30. Cook, G. C. 1969. Absorption products of D(-) fructose in man. Clin. Sci. (Oxf.). 37: 675-687.

31. Marliss, E. B., and T. T. Aoki. 1972. Hormonal regulation of amino acid metabolism in man. Relation to fasting and other physiologic and pathologic states. Acta Diabetol. Lat. 9(Suppl. 1) : 189-225.

32. Felig, P., E. Marliss, and G. F. Cahill, Jr. 1969. Plasma amino acid levels and insulin secretion in obesity. $N$. Engl. J. Med. 281: 811-816.

33. Adibi, S. A. 1968. Influence of dietary deprivations on plasma concentration of free amino acids of man. J. Appl. Physiol. 25: 52-57.

34. Poznanski, W. J. 1969. Hormonal influences on plasma amino acid(s) levels in man. In Protein and Polypeptide Hormones. M. Margoulies, editor. Excerpta Medica Foundation, Amsterdam. 542-546.

35. Swendseid, M. E., S. G. Tuttle, E. J. Drenick, C. B. Joven, and F. J. Massey. 1967. Plasma amino acid response to glucose administration in various nutritive states. Am. J. Clin. Nutr. 20: 243-249.

36. Zinneman, H. H., F. Q. Nuttall, and F. C. Goetz, 1966. Effect of endogenous insulin on human amino acid metabolism. Diabctes. 15: 5-8.

37. Crofford, O. B., P. W. Felts, and W. W. Lacy. 1964. Effect of glucose infusion on the individual plasma free amino acids in man. Proc. Soc. Exp. Biol. Med. 117: 11-14.

38. Pozefsky, T., P. Felig, J. D. Tobin, S. S. Soeldner, and G. F. Cahill, Jr. 1969. Amino acid balance across tissues of the forearm in postabsorptive man. Effects of insulin at two dose levels. J. Clin. Invest. 48: 2273-2282.

39. Felig, P., J. Wahren, R. Hendler, and T. Brundin. 1974. Splanchnic glucose and amino acid metabolism in obesity. J. Clin. Invest. 53: 582-590.

40. Felig, P., J. Wahren, and R. Hendler. 1974. Primary role of the liver in the disposal and metabolic response to oral glucose. Clin. Res. 22: 467A. (Abstr.)

41. Mendeloff, A. I., and T. W. Weichselbaum. 1953. Role of the human liver in the assimilation of intravenously administered fructose. Metab. Clin. Exp. 2: 450-458.
42. Van Itallie, T. B., M. C. Morgan, R. T. Cathcart, G. G. Leduc, and L. B. Dotti. 1953. Peripheral assimilation of fructose in man. Proc. Soc. Exp. Biol. Med. 84: 713715 .

43. Miller, M., J. W. Craig, W. R. Drucker, and H. Woodward, Jr. 1956. The metabolism of fructose in man. Yalc J. Biol. Med. 29: 335-360.

44. Froesch, E. R., and J. L. Ginsberg. 1962. Fructose metabolism of adipose tissue. I. Comparison of fructose and glucose metabolism in epididymal adipose tissue of normal rats. J. Biol. Chem. 237: 3317-3324.

45. Steinberg, S. J. 1927. Zur frage der assimilation der lävulose. Pflügers Archiv. Gesamte Physiol. Menschen Tiere. 217: 686-695.

46. Bergström, J., and E. Hultman. 1967. Synthesis of muscle glycogen in man after glucose and fructose infusion. Acta Med. Scand. 182: 93-107.

47. Ellis, D. A., J. M. Strickland, and J. F. Eccleston. 1973. The direct interconversion of glucose and fructose in human skeletal muscle with special reference to childhood muscular dystrophy. Clin. Sci. (Oxf.). 44: 321334.

48. Felig, P. 1973. The glucose-alanine cycle. Metab. Clin. Exp. 22: 179-207.

49. Pagliara, A. S., I. E. Karl, D. C. De Vivo, R. D. Feigin, and D. M. Kipnis. 1972. Hypoalaninemia : a concomitant of ketotic hypoglycemia. J. Clin. Invest. 51: 1440-1449.

50. Sizonenko, P. C., L. Paunier, M. B. Vallotton, G. S. Cuendet, G. Zahnd, and E. B. Marliss. 1973. Response to 2-deoxy-D-glucose and to glucagon in "ketotic hypoglycemia" of childhood: evidence for epinephrine deficiency and altered alanine availability. Pediatr. Res. 7: 983-993.

51. Wolfe, B. M., and L. Belbeck. 1972. Hepatic production of lactate during hypercaloric dextrose infusion in miniature swine. Clin. Res. 20: 561. (Abstr.)

52. Cherry, I. S., and L. A. Crandall, Jr. 1937. The response of the liver to the oral administration of glucose. $A m$. J. Physiol. 124: 52-58.

53. Jackson, R. A., U. Advani, G. Perry, J. Rogers, N. Peters, S. Day, and T. R. E. Pilkington. 1973. Dietary diabetes. The influence of a low carbohydrate diet on forearm metabolism in man. Diabetes. 22: 145-159.

54. Jandl, J. H., and R. H. Aster. 1967. Increased splenic pooling and the pathogenesis of hypersplenism. Am. J. Med. Sci. 253: 383-398.

55. Cahill, G. F., Jr., and O. E. Owen. 1968. Some observations on carbohydrate metabolism in man. In Carbohydrate Metabolism and Its Disorders. F. Dickens, P. J. Randle, and W. J. Whelan, editors. Academic Press Inc., Ltd., London. 498-522.

56. Tygstrup, N., K. Winkler, and F. Lundquist. 1965. The mechanism of the fructose effect on the ethanol metabolism of the human liver. J. Clin. Invest. 44: 817-830.

57. Gordon, E. E., and A. Craigie. 1960. Effect of intravenous glucose on splanchnic and peripheral metabolism of endogenous pyruvate and citrate in patients with cirrhosis and in subjects without liver disease. J. Lab. Clin. Med. 55: 841-848.

58. Wolfe, B., and S. Ahuja. 1973. Triglyceride secretion during fructose versus glucose consumption in hyperlipemia. Circulation. 48: IV-16. 